\title{
Correlation between endothelial function and carotid atherosclerosis in rheumatoid arthritis patients with long-standing disease
}

\author{
Carlos González-Juanatey ${ }^{1}$, Javier Llorca² and Miguel A González-Gay ${ }^{3^{*}}$
}

\begin{abstract}
Introduction: In this study, we aimed to determine the relationship between flow-mediated endotheliumdependent vasodilatation (FMD) and carotid artery intima-media wall thickness (IMT), two surrogate markers of atherosclerosis, in a series of Spanish patients with rheumatoid arthritis (RA) without clinically evident cardiovascular (CV) disease.
\end{abstract}

Methods: One hundred eighteen patients who fulfilled the 1987 American College of Rheumatology classification criteria for RA, had no history of CV disease and had at least one year of follow-up after disease diagnosis were randomly selected. Brachial and carotid ultrasonography were performed to determine FMD and carotid IMT, respectively.

Results: Carotid IMT values were higher and FMD percentages derived by performing ultrasonography were lower in individuals with a long duration from the time of disease diagnosis. Patients with a disease duration $\leq 7$ years had significantly lower carotid IMT (mean \pm SD) $0.69 \pm 0.17 \mathrm{~mm}$ than those with long disease duration $(0.81 \pm 0.12$ $\mathrm{mm}$ in patients with $\geq 20$ years of follow-up). Also, patients with a long disease duration had severe endothelial dysfunction (FMD $4.0 \pm 4.0 \%$ in patients with disease duration from 14.5 to 19.7 years) compared with those with shorter disease duration (FMD $7.4 \pm 3.8 \%$ in patients with disease duration $\leq 7$ years). Linear regression analysis revealed that carotid IMT was unrelated to FMD in the whole sample of 118 patients. However, carotid IMT was negatively associated with FMD when the time from disease diagnosis ranged from 7.5 to 19.7 years $(P=0.02)$.

Conclusions: In patients with RA without CV disease, endothelial dysfunction and carotid IMT increased with the duration of RA. The association between FMD and carotid IMT values was observed only in patients with long disease duration.

\section{Introduction}

Rheumatoid arthritis (RA) is a chronic inflammatory disease associated with increased incidence of cardiovascular (CV) mortality [1,2]. This is the result of accelerated atherosclerosis [3]. Because of the high incidence of CV events observed in patients with RA, an important step forward might be to identify high-risk individuals who would benefit from active therapy to prevent clinical disease. In this regard, several noninvasive imaging techniques offer clinicians a unique opportunity to study the relationship of surrogate markers to the development of

\footnotetext{
* Correspondence: miguelaggay@hotmail.com

${ }^{3}$ Department of Rheumatology, Hospital Universitario Marqués de Valdecilla, IFIMAV, Avenida de Valdecilla s/n, E-39008, Santander, Spain

Full list of author information is available at the end of the article
}

atherosclerosis. Among them, ultrasound techniques based on flow velocity and intimal thickness are considered efficient ways to measure subclinical atherosclerosis. Using brachial artery ultrasonography assessment, we and others have found the presence of endothelial dysfunction expressed by abnormal levels of flow-mediated endothelium-dependent vasodilatation (FMD) in patients without clinically evident $\mathrm{CV}$ disease who had either long-standing RA [4] or early-onset RA [5]. Moreover, increased carotid artery intima-media wall thickness (IMT) and increased frequency of carotid plaques have been described in RA patients with or without classic CV risk factors compared to ethnically matched controls [6-11]. Also, besides an association of carotid IMT with markers of inflammation $[12,13]$, the duration of the

\section{Ciomed Central}


disease has been associated with an increase in carotid IMT [14] and the presence of carotid plaques [8,11]. This is in accordance with data showing progression of carotid IMT in RA patients with long-standing, severe disease despite treatment with anti-TNF- $\alpha$ therapy [15]. Interestingly, a recent observation disclosed that carotid IMT may predict the development of $\mathrm{CV}$ events in patients with RA [16].

Since FMD constitutes a physiologic assessment of endothelial dysfunction and carotid IMT is an anatomic structural measure of subclinical atherosclerosis, it is logical that FMD might be a more useful diagnostic marker than carotid IMT in the early stages of the disease. In contrast, carotid IMT might be considered in the assessment of $\mathrm{CV}$ risk among patients with longstanding RA.

No relationship between carotid IMT and brachial artery FMD was found in middle-aged men without a history of $\mathrm{CV}$ disease who were considered to be at low or intermediate risk for future CV events based on current risk stratification algorithms [17]. However, because of the increased risk of CV events, this may not be the case for patients with long-standing RA.

Taking into consideration all of these factors together, and based on the experience of our group in the study of subclinical atherosclerosis not only in RA but also in other chronic inflammatory rheumatic diseases using ultrasound techniques [18-20], in the present study we aimed to determine the relationship between FMD and carotid IMT in RA patients without clinically evident CV disease.

\section{Materials and methods \\ Patients and study protocol}

Between January 2008 and December 2009, a series of 118 patients attending the rheumatology outpatient clinic of Hospital Xeral-Calde, Lugo, Spain, who fulfilled the 1987 American College of Rheumatology classification criteria for RA [21] and had no history of CV disease and but had at least one year of follow-up from their disease diagnosis were randomly selected for ultrasonographic assessment. To determine whether endothelial dysfunction was present, FMD was assessed by brachial ultrasonography as previously reported $[18,22]$. An FMD value $<7 \%$ was considered pathologic, indicating the presence of endothelial dysfunction [22]. Intraobserver variability for FMD and NTG was $1.3 \%$ and $1.9 \%$, respectively, based on repeat brachial ultrasonography in 32 healthy controls. Assessment of the endothelial function of patients undergoing anti-TNF- $\alpha$ therapy was performed 24 to 48 hours before drug administration. Also, carotid ultrasonography was performed to determine carotid artery IMT. IMT was assessed in the right common carotid artery as previously reported [19,22]. On the basis of a second carotid ultrasonography performed in $20 \mathrm{RA}$ patients and 20 healthy controls within one week after the first assessment, the correlation coefficient for carotid IMT was 0.98. The main epidemiological data of this series of patients are shown in Table 1. The patients' written consent was obtained according to the Declaration of Helsinki, and the design of the work was approved by the Ethics Committee of Galicia (Spain).

\section{Statistical analysis}

Quantitative variables are described using means and standard deviations (SDs) and medians and interquartile ranges (IQRs), and qualitative variables are described as numbers and percentages. The relationship between carotid IMT (as a dependent variable) and FMD (as an independent variable) was explored using linear regression, adjusting for gender, age at the time of RA diagnosis and years from RA disease diagnosis to ultrasonographic assessment. To further explore this relationship, we repeated the regression analysis by stratifying patients into quartiles defined by the time from RA diagnosis to ultrasonographic evaluation.

\section{Results}

Patients with RA were stratified into four quartiles according to the time from disease diagnosis to ultrasonographic assessment (Table 2). Following this procedure, we observed that carotid IMT values were greater in individuals with a longer duration from disease diagnosis to ultrasonographic assessment $(P<0.001)$. In this regard, carotid IMT values were higher if time from RA diagnosis was longer than its median (that is, > 14 years). With respect to this observation, individuals with disease duration from RA diagnosis $\leq 7$ years had significantly lower carotid IMT wall thickness $(0.69 \pm 0.17 \mathrm{~mm})$ than did those with long disease duration $(0.81 \pm 0.12 \mathrm{~mm}$ in

Table 1 Main epidemiologic data for 118 patients with RA who underwent ultrasonography ${ }^{\text {a }}$

\begin{tabular}{lcc}
\hline Variable & Mean \pm SD or number of patients (\%) & Median (IQR) \\
\hline Age at the time of the study, years & $58.4 \pm 12.9$ & $59.5(49$ to 68.5$)$ \\
Disease duration from RA diagnosis, years & $13.8 \pm 7.7$ & $14(7$ to 19.7$)$ \\
Women & $89(75.4 \%)$ & $96(81.4 \%)$ \\
Rheumatoid factor-positive &
\end{tabular}

${ }^{\mathrm{a}} \mathrm{RA}$ : rheumatoid arthritis, SD: standard deviation, IQR: interquartile range. 
Table 2 Distribution of carotid IMT and FMD in RA patients stratified into four quartiles according to time from disease diagnosis to ultrasonography ${ }^{a}$

\begin{tabular}{lcc}
\hline Time from RA diagnosis to ultrasonography & Carotid IMT $(\mathbf{m m})$ mean \pm SD & FMD (\%) mean \pm SD \\
\hline Quartile 1, one to seven years & $0.69 \pm 0.17$ & $7.4 \pm 3.8$ \\
Quartile 2, 7.5 to 14 years & $0.68 \pm 0.16$ & $6.6 \pm 4.6$ \\
Quartile 3, 14.5 to 19.7 years & $0.84 \pm 0.24$ & $4.0 \pm 4.0$ \\
Quartile 4, 20 to 38 years & $0.81 \pm 0.12$ & $3.3 \pm 4.4$ \\
$P$ value & $<0.001$ & $<0.001$ \\
\hline
\end{tabular}

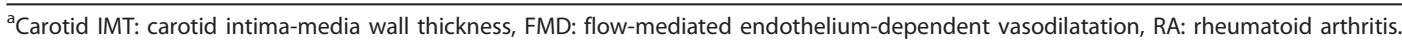

individuals with at least 20 years of follow-up from the time of RA diagnosis). Likewise, FMD decreased as time from RA diagnosis increased $(P<0.001)$. As shown in the carotid artery ultrasonographic evaluation, individuals with longer disease duration from disease diagnosis had severe endothelial dysfunction (FMD $4.0 \pm 4.0 \%$ in RA patients with disease duration between 14.5 and 19.7 years versus $3.3 \pm 4.4 \%$ in those with disease duration $\geq 20$ years) compared with RA patients who had shorter disease duration (FMD $7.4 \pm 3.8 \%$ in patients with disease duration $\leq 7$ years).

To explore the relationship between FMD and carotid IMT, linear regression analysis was performed. This analysis disclosed that carotid IMT was unrelated to FMD endothelium-dependent vasodilatation in the whole sample of 118 patients (Table 3). However, when patients with RA were stratified according to the time from disease diagnosis until the time of ultrasonography, carotid IMT was negatively associated with FMD when the time from disease diagnosis ranged from 7.5 to 19.7 years $(P=$ 0.02 ). In patients included in this range of disease duration, the higher FMD percentages were associated with thinner (that is, lower) carotid IMT values (Figure 1). However, in patients with shorter disease duration (one to seven years) or longer disease duration ( $\geq 20$ years), FMD and carotid IMT values remained unrelated (Table 4).

\section{Discussion}

A series of cellular, molecular and pathophysiological events occur during the progression of RA and may also be involved first in endothelial dysfunction and later in atherosclerosis [23]. A healthy endothelium prevents adhesion of mononuclear cells. Inflammation promotes

Table 3 Regression analysis between carotid IMT and FMD $^{a}$

Variable Correlation coefficient (95\% confidence interval) $P$ value

\begin{tabular}{lll}
\hline FMD $^{\mathrm{b}}$ & $-0.003(-0.009$ to 0.003$)$ & 0.35 \\
\hline
\end{tabular}

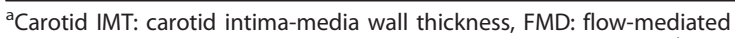
endothelium-dependent vasodilatation, RA: rheumatoid arthritis; ${ }^{\mathrm{b}}$ Adjusted for gender, age at the time of disease diagnosis and years from RA diagnosis to ultrasonography assessment. endothelial cell activation, which is characterized by loss of vascular integrity, increased expression of leukocyte adhesion molecules such as selectins, vascular cell adhesion molecule 1 and intercellular adhesion molecule 1 (ICAM-1); change in phenotype from antithrombotic to thrombotic; production of several cytokines; and upregulation of human leukocyte antigen molecules. All of these changes allow endothelial cells to participate in the inflammatory response. In this process, the increased expression of adhesion molecules promotes the adherence and migration of monocytes into the vessel wall. Differentiation of monocytes into macrophages in the intima and activation and further differentiation to form cells characterize the development of early atherosclerotic lesions $[24,25]$. Continuous endothelial cell activation, manifested by increased levels of the adhesion molecules soluble ICAM-1 and sE-selectin, is present in patients with RA [26]. This endothelial cell activation subsequently leads to endothelial dysfunction, which is an important event in early atherogenesis and also contributes to the development of clinical features in the later stages of the vascular disease, including the

Time from diagnosis: $7.5-19.7$ years ( $2^{\text {nd }}-3^{\text {rd }}$ quartiles)

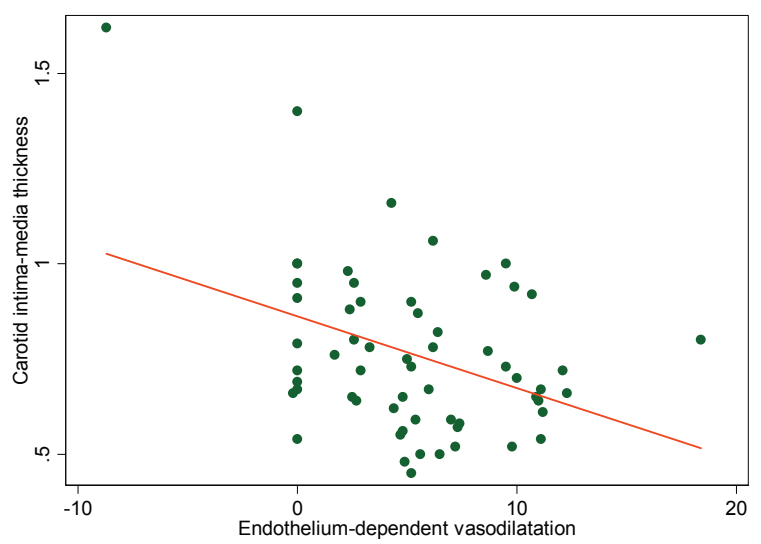

Figure 1 Scatterplot illustrating the relationships between FMD and carotid IMT in patients with RA and disease duration ranging between 7 and 20 years derived using linear regression analysis. 
Table 4 Regression analysis between carotid IMT and FMD stratified by disease duration from the time of RA diagnosis until ultrasonography assessment ${ }^{a}$

\begin{tabular}{lcc}
\hline Time from RA diagnosis until ultrasonography & Correlation coefficient (95\% confidence interval) & $P$ value \\
\hline Quartile 1, one to seven years & $-0.003(-0.019$ to 0.013$)$ & 0.82 \\
Quartiles 2 and 3, 7.5 to 19.7 years & $-0.012(-0.021$ to -0.003$)$ & 0.02 \\
Quartile 4, 20 to 38 years & $0.008(-0.003$ to 0.019$)$ & 0.27 \\
\hline
\end{tabular}

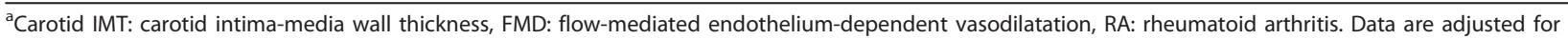
gender, age at time of diseaseand time from RA diagnosis until ultrasonography.

progression of atherosclerotic plaque [27]. Interestingly, Kerekes et al. [28] showed that disease duration was associated with impaired FMD and several biomarkers of inflammation. Although in the present study we found no impairment of endothelial function as determined on the basis of brachial FMD in patients with $<7$ years' disease duration, longer disease duration, particularly $>14$ years, was associated with severe endothelial dysfunction. In keeping with this observation, Södergren et al. [29] found no impairment in endothelial function, measured as FMD, among patients with newly diagnosed RA compared with controls.

With regard to carotid ultrasonography, it is known that a common carotid artery IMT $\geq 0.60 \mathrm{~mm}$ is a marker of atherosclerosis [30,31]. In addition, both carotid artery IMT $>0.90 \mathrm{~mm}$ and the presence of carotid plaques are considered to be expression of subclinical organ damage and factors influencing $\mathrm{CV}$ prognosis in the general population [32]. Interestingly, a recent metaanalysis demonstrated an increased carotid IMT in patients with early RA [33]. Although the increase in carotid IMT in this meta-analysis was much lower than expected in view of the almost doubled $\mathrm{CV}$ risk in RA patients [33], carotid IMT was proven to predict the development of CV events in RA patients [16]. Because of that finding, the presence of abnormally high carotid IMT values should be raise clinical suspicions as a sign of the development of CV complications in these patients. In the present study, we observed that individuals with long disease duration ( $>14$ years) had abnormally high carotid IMT values. With respect to this observation, on the basis of 631 consecutive RA patients, del Rincón et al. [14] showed that IMT increases per unit of age in proportion to RA duration. In del Rincón et al.'s study [14], carotid IMT increased from $0.154 \mathrm{~mm} / 10$ years among patients with RA for $\leq$ 7 years to $0.295 \mathrm{~mm} / 10$ years among patients with RA for $\geq 20$ years.

In line with the above findings, using electron-beam computed tomography to measure the extent of coronary artery calcification, Chung et al. [34] found that coronary-artery calcification occurred more frequently in patients with established RA than in patients with early RA and controls. A question that needs to be answered is whether carotid ultrasonography and brachial FMD should routinely be performed in all patients with RA to improve $\mathrm{CV}$ risk management. With respect to this question, carotid IMT was found to be an independent predictor of vascular events in high-risk individuals without RA in whom risk factors were managed clinically [35]. Since the risk of CV disease is increased in patients with RA, carotid ultrasound might be a potential additional tool for stratifying $\mathrm{CV}$ risk in patients with RA [22]. In this regard, a recent study by Evans et al. [36] showed that the presence of carotid plaques in both internal carotid arteries following carotid ultrasonography nearly quadrupled the incidence of new acute coronary syndromes in patients with RA compared with those in RA patients without carotid plaques. On the hand, impaired FMD of the brachial artery due to endothelial dysfunction has been associated with both $\mathrm{CV}$ risk factors and future $\mathrm{CV}$ morbidity and mortality in the general population [37]. In addition, endothelial dysfunction manifested by impaired FMD was observed in both long-standing RA patients [4] and early-onset RA patients [5] without clinically evident CV disease. These observations support a potential role of FMD in establishing the presence of endothelial dysfunction as a subclinical marker of atherosclerotic disease in RA. They may also provide a basis for the association between RA and atherosclerotic disease.

Of main clinical relevance may be the improvement in endothelial function observed in patients with RA following treatment with TNF- $\alpha$ blockers [38-40] or rituximab $[41,42]$. However, the beneficial effect of the TNF- $\alpha$ antagonist infliximab on endothelial dysfunction seems to be only temporary [43]. Conflicting results have been described regarding the effects of biologic agents on carotid atherosclerosis [44]. In this regard, while some patients showed significant improvement in carotid IMT following TNF- $\alpha$ blocker therapy [45], others did not experience reduction of IMT following treatment with these drugs $[15,40,46]$.

Previous observations showed no relationship between carotid IMT and brachial artery FMD in middle-aged men at low and intermediate risk of experiencing future $\mathrm{CV}$ events [17]. However, the situation might not be the same in patients with long-standing RA. Therefore, we aimed to determine the relationship between both techniques in patients with RA. On the basis of linear 
regression analysis, we found that carotid IMT was unrelated to FMD in the whole sample of 118 patients. This observation was also in keeping with another study performed in elderly individuals that showed no correlation between brachial FMD and carotid IMT [47]. However, our data suggest that in patients with disease duration ranging between from 7.5 to 19.7 years, carotid IMT is negatively associated with brachial FMD.

\section{Conclusions}

In summary, our results reinforce the importance of disease duration in the development of atherosclerosis in patients with RA. Brachial FMD and carotid IMT may indicate distinct and independent stages in the complex pathways leading to accelerated atherosclerosis in patients with RA.

\section{Abbreviations}

CV: cardiovascular; IMT: intima-media thickness; IQR: interquartile range; FMD: endothelium-dependent flow-mediated vasodilatation; RA: rheumatoid arthritis; SD: standard deviation.

\section{Acknowledgements}

This study was supported by "Fondo de Investigaciones Sanitarias" grants PI06-0024 and PS09/00748 (Spain). This work was partially supported by the RETICS Program, RD08/0075 (RIER), from "Instituto de Salud Carlos III" (ISCIII).

\section{Author details}

${ }^{1}$ Cardiology Division, Hospital Xeral-Calde, c/Dr. Ochoa s/n, Lugo E-27004, Spain. ${ }^{2}$ Department of Epidemiology and Computational Biology, School of Medicine, University of Cantabria, and CIBER Epidemiología y Salud Pública (CIBERESP), IFIMAV, Avenida Herrera Oria s/n, E-39011 Santander, Spain. ${ }^{3}$ Department of Rheumatology, Hospital Universitario Marqués de Valdecilla, IFIMAV, Avenida de Valdecilla s/n, E-39008, Santander, Spain.

\section{Authors' contributions}

CGJ performed the ultrasonographic studies, participated in the design of the study and helped to draft the manuscript. $J L$ participated in the design of the study and data analysis and helped to draft the manuscript. MAGG made substantial contributions to the conception and design of the study, the acquisition of data and the coordination of the study. All authors read and approved the final version of the manuscript to be published.

\section{Competing interests}

The authors declare that they have no competing interests.

Received: 8 March 2011 Revised: 17 May 2011 Accepted: 22 June 2011 Published: 22 June 2011

\section{References}

1. Goodson N, Marks J, Lunt M, Symmons D: Cardiovascular admissions and mortality in an inception cohort of patients with rheumatoid arthritis with onset in the 1980s and 1990s. Ann Rheum Dis 2005, 64:1595-1601.

2. Solomon DH, Karlson EW, Rimm EB, Cannuscio CC, Mandl LA, Manson JE, Stampfer MJ, Curhan GC: Cardiovascular morbidity and mortality in women diagnosed with rheumatoid arthritis. Circulation 2003, 107:1303-1307.

3. González-Gay MA, González-Juanatey C, Martin J: Rheumatoid arthritis: a disease associated with accelerated atherogenesis. Semin Arthritis Rheum 2005, 35:8-17.

4. González-Juanatey C, Testa A, Garcia-Castelo A, Garcia-Porrua C, Llorca J, Vidan J, Hajeer AH, Ollier WE, Mattey DL, González-Gay MA: HLA-DRB1 status affects endothelial function in treated patients with rheumatoid arthritis. Am J Med 2003, 114:647-652.
5. Vaudo G, Marchesi S, Gerli R, Allegrucci R, Giordano A, Siepi D, Pirro M, Shoenfeld $Y$, Schillaci G, Mannarino E: Endothelial dysfunction in young patients with rheumatoid arthritis and low disease activity. Ann Rheum Dis 2004, 63:31-35.

6. Kumeda $Y$, Inaba $M$, Goto $H$, Nagata $M$, Henmi $Y$, Furumitsu $Y$, Ishimura $E$, Inui K, Yutani Y, Miki T, Shoji T, Nishizawa Y: Increased thickness of the arterial intima-media detected by ultrasonography in patients with rheumatoid arthritis. Arthritis Rheum 2002, 46:1489-1497.

7. Park YB, Ahn CW, Choi HK, Lee SH, In BH, Lee HC, Nam CM, Lee SK: Atherosclerosis in rheumatoid arthritis: morphologic evidence obtained by carotid ultrasound. Arthritis Rheum 2002, 46:1714-1719.

8. González-Juanatey C, Llorca J, Testa A, Revuelta J, Garcia-Porrua C González-Gay MA: Increased prevalence of severe subclinical atherosclerotic findings in long-term treated rheumatoid arthritis patients without clinically evident atherosclerotic disease. Medicine (Baltimore) 2003, 82:407-413.

9. Alkaabi JK, Ho M, Levison R, Pullar T, Belch JJ: Rheumatoid arthritis and macrovascular disease. Rheumatology (Oxford) 2003, 42:292-297.

10. Abu-Shakra M, Polychuck I, Szendro G, Bolotin A, Jonathan BS, Flusser D, Buskila D, Sukenik S: Duplex study of the carotid and femoral arteries of patients with rheumatoid arthritis: a controlled study. Semin Arthritis Rheum 2005, 35:18-23.

11. Roman MJ, Moeller E, Davis A, Paget SA, Crow MK, Lockshin MD, Sammaritano L, Devereux RB, Schwartz JE, Levine DM, Salmon JE: Preclinical carotid atherosclerosis in patients with rheumatoid arthritis. Ann Intern Med 2006, 144:249-256.

12. del Rincón I, Williams K, Stern MP, Freeman GL, O'Leary DH, Escalante A Association between carotid atherosclerosis and markers of inflammation in rheumatoid arthritis patients and healthy subjects. Arthritis Rheum 2003, 48:1833-1840.

13. González-Gay MA, González-Juanatey C, Piñeiro A, Garcia-Porrua C, Testa A Llorca J: High-grade C-reactive protein elevation correlates with accelerated atherogenesis in patients with rheumatoid arthritis. $J$ Rheumatol 2005, 32:1219-1223.

14. del Rincón I, O'Leary DH, Freeman GL, Escalante A: Acceleration of atherosclerosis during the course of rheumatoid arthritis. Atherosclerosis 2007, 195:354-360.

15. González-Juanatey C, Llorca J, Garcia-Porrua C, Martin J, González-Gay MA: Effect of anti-tumor necrosis factor a therapy on the progression of subclinical atherosclerosis in severe rheumatoid arthritis. Arthritis Rheum 2006, 55:150-153.

16. González-Juanatey C, Llorca J, Martin J, González-Gay MA: Carotid intimamedia thickness predicts the development of cardiovascular events in patients with rheumatoid arthritis. Semin Arthritis Rheum 2009, 38:366-371.

17. Yan RT, Anderson TJ, Charbonneau F, Title L, Verma S, Lonn E: Relationship between carotid artery intima-media thickness and brachial artery flowmediated dilation in middle-aged healthy men. J Am Coll Cardiol 2005, 45:1980-1986

18. González-Juanatey C, Llorca J, Miranda-Filloy JA, Amigo-Diaz E, Testa A, Garcia-Porrua C, Martin J, González-Gay MA: Endothelial dysfunction in psoriatic arthritis patients without clinically evident cardiovascular disease or classic atherosclerosis risk factors. Arthritis Rheum 2007 57:287-293.

19. González-Juanatey C, Llorca J, Amigo-Diaz E, Dierssen T, Martin J, GonzálezGay MA: High prevalence of subclinical atherosclerosis in psoriatic arthritis patients without clinically evident cardiovascular disease or classic atherosclerosis risk factors. Arthritis Rheum 2007, 57:1074-1080.

20. González-Juanatey C, Vazquez-Rodriguez TR, Miranda-Filloy JA, Dierssen T, Vaqueiro I, Blanco R, Martin J, Llorca J, González-Gay MA: The high prevalence of subclinical atherosclerosis in patients with ankylosing spondylitis without clinically evident cardiovascular disease. Medicine (Baltimore) 2009, 88:358-365.

21. Arnett FC, Edworthy SM, Bloch DA, McShane DJ, Fries JF, Cooper NS, Healey LA, Kaplan SR, Liang MH, Luthra HS, Medsger TA Jr, Mitchell DM, Neustadt DH, Pinals RS, Schaller JG, Sharp JT, Wilder RL, Hunder GG: The American Rheumatism Association 1987 revised criteria for the classification of rheumatoid arthritis. Arthritis Rheum 1988, 31:315-324.

22. González-Gay MA, González-Juanatey C, Vazquez-Rodriguez TR, Martin J, Llorca J: Endothelial dysfunction, carotid intima-media thickness, and accelerated atherosclerosis in rheumatoid arthritis. Semin Arthritis Rheum 2008, 38:67-70. 
23. González-Gay MA, González-Juanatey C, Martin J: Inflammation and endothelial dysfunction in rheumatoid arthritis. Clin Exp Rheumatol 2006, 24:115-117.

24. Libby P, Ridker PM, Maseri A: Inflammation and atherosclerosis. Circulation 2002, 105:1135-1143

25. Bijl M: Endothelial activation, endothelial dysfunction and premature atherosclerosis in systemic autoimmune diseases. Neth J Med 2003, 61:273-277.

26. Wållberg-Jonsson S, Cvetkovic JT, Sundqvist KG, Lefvert AK, RantapääDahlqvist S: Activation of the immune system and inflammatory activity in relation to markers of atherothrombotic disease and atherosclerosis in rheumatoid arthritis. J Rheumatol 2002, 29:875-882.

27. Vita JA, Keaney JF Jr: Endothelial function: a barometer for cardiovascular risk? Circulation 2002, 106:640-642.

28. Kerekes G, Szekanecz Z, Dér H, Sándor Z, Lakos G, Muszbek L, Csipö I, Sipka S, Seres I, Paragh G, Kappelmayer J, Szomják E, Veres K, Szegedi G, Shoenfeld $Y$, Soltész P: Endothelial dysfunction and atherosclerosis in rheumatoid arthritis: a multiparametric analysis using imaging techniques and laboratory markers of inflammation and autoimmunity. J Rheumatol 2008, 35:398-406.

29. Södergren A, Karp K, Boman K, Eriksson C, Lundström E, Smedby T, Söderlund L, Rantapää-Dahlqvist S, Wållberg-Jonsson S: Atherosclerosis in early rheumatoid arthritis: very early endothelial activation and rapid progression of intima media thickness. Arthritis Res Ther 2010, 12:R158.

30. Veller MG, Fisher CM, Nicolaides AN, Renton S, Geroulakos G, Stafford NJ, Sarker A, Szendro G, Belcaro G: Measurement of the ultrasonic intimamedia complex thickness in normal subjects. J Vasc Surg 1993, 17:719-725.

31. Belcaro G, Nicolaides AN, Ramaswami G, Cesarone MR, De Sanctis M, Incandela L, Ferrari P, Geroulakos G, Barsotti A, Griffin M, Dhanjil S, Sabetai M, Bucci M, Martines G: Carotid and femoral ultrasound morphology screening and cardiovascular events in low risk subjects: a 10-year follow-up study (the CAFES-CAVE study). Atherosclerosis 2001, 156:379-387.

32. Mancia G, De Backer G, Dominiczak A, Cifkova R, Fagard R, Germano G, Grassi G, Heagerty AM, Kjeldsen SE, Laurent S, Narkiewicz K, Ruilope L, Rynkiewicz A, Schmieder RE, Boudier HA, Zanchetti A, Vahanian A, Camm J, De Caterina R, Dean V, Dickstein K, Filippatos G, Funck-Brentano C, Hellemans I, Kristensen SD, McGregor K, Sechtem U, Silber S, Tendera M Widimsky P, Management of Arterial Hypertension of the European Society of Hypertension, European Society of Cardiology, et al: Guidelines for the Management of Arterial Hypertension: The Task Force for the Management of Arterial Hypertension of the European Society of Hypertension (ESH) and of the European Society of Cardiology (ESC). $J$ Hypertens 2007, 25:1105-1187, A published erratum appears in J Hypertens 2007, 25:1749

33. van Sijl AM, Peters MJ, Knol DK, de Vet HC, González-Gay MA, Smulders YM, Dijkmans BA, Nurmohamed MT: Carotid intima media thickness in rheumatoid arthritis as compared to control subjects: a meta-analysis. Semin Arthritis Rheum 2011, 40:389-397.

34. Chung CP, Oeser A, Raggi P, Gebretsadik T, Shintani AK, Sokka T, Pincus T, Avalos I, Stein CM: Increased coronary-artery atherosclerosis in rheumatoid arthritis: relationship to disease duration and cardiovascular risk factors. Arthritis Rheum 2005, 52:3045-3053.

35. Kitagawa K, Hougaku H, Yamagami H, Hashimoto H, Itoh T, Shimizu Y, Takahashi D, Murata S, Seike Y, Kondo K, Hoshi T, Furukado S, Abe Y, Yagita Y, Sakaguchi M, Tagaya M, Etani H, Fukunaga R, Nagai Y, Matsumoto M, Hori M, OSACA2 Study Group: Carotid intima-media thickness and risk of cardiovascular events in high-risk patients: results of the Osaka Follow-Up Study for Carotid Atherosclerosis 2 (OSACA2 Study). Cerebrovasc Dis 2007, 24:35-42.

36. Evans MR, Escalante A, Battafarano DF, Freeman GL, O'Leary DH, del Rincón I: Carotid atherosclerosis predicts incident acute coronary syndromes in rheumatoid arthritis. Arthritis Rheum 2011, 63:1211-1120.

37. Ter Avest $E$, Stalenhoef AF, de Graaf J: What is the role of non-invasive measurements of atherosclerosis in individual cardiovascular risk prediction? Clin Sci (Lond) 2007, 112:507-516.

38. Hürlimann D, Forster A, Noll G, Enseleit F, Chenevard R, Distler O, Béchir M, Spieker LE, Neidhart M, Michel BA, Gay RE, Lüscher TF, Gay S, Ruschitzka F: Anti-tumor necrosis factor-a treatment improves endothelial function in patients with rheumatoid arthritis. Circulation 2002, 106:2184-2187.
39. González-Juanatey C, Llorca J, Sanchez-Andrade A, Garcia-Porrua C, Martin J, González-Gay MA: Short-term adalimumab therapy improves endo-thelial function in patients with rheumatoid arthritis refractory to infliximab. Clin Exp Rheumatol 2006, 24:309-312.

40. Sidiropoulos Pl, Siakka P, Pagonidis K, Raptopoulou A, Kritikos H, Tsetis D, Boumpas DT: Sustained improvement of vascular endothelial function during anti-TNFa treatment in rheumatoid arthritis patients. Scand J Rheumatol 2009, 38:6-10.

41. González-Juanatey C, Llorca J, Vazquez-Rodriguez TR, Diaz-Varela N, GarciaQuiroga H, González-Gay MA: Short-term improvement of endothelial function in rituximab-treated rheumatoid arthritis patients refractory to tumor necrosis factor a blocker therapy. Arthritis Rheum 2008, 59:1821-1824.

42. Kerekes G, Soltész P, Dér H, Veres K, Szabó Z, Végvári A, Szegedi G, Shoenfeld $Y$, Szekanecz $Z$ : Effects of rituximab treatment on endothelial dysfunction, carotid atherosclerosis, and lipid profile in rheumatoid arthritis. Clin Rheumatol 2009, 28:705-710.

43. González-Juanatey C, Testa A, Garcia-Castelo A, Garcia-Porrua C, Llorca J, González-Gay MA: Active but transient improvement of endothelial function in rheumatoid arthritis patients undergoing long-term treatment with anti-tumor necrosis factor a antibody. Arthritis Rheum 2004, 51:447-450.

44. Szekanecz Z, Kerekes G, Soltész P: Vascular effects of biologic agents in RA and spondyloarthropathies. Nat Rev Rheumatol 2009, 5:677-684

45. Del Porto F, Laganà B, Lai S, Nofroni I, Tinti F, Vitale M, Podestà E, Mitterhofer AP, D'Amelio R: Response to anti-tumour necrosis factor a blockade is associated with reduction of carotid intima-media thickness in patients with active rheumatoid arthritis. Rheumatology (Oxford) 2007, 46:1111-1115.

46. Wong M, Oakley SP, Young L, Jiang BY, Wierzbicki A, Panayi G, Chowienczyk P, Kirkham B: Infliximab improves vascular stiffness in patients with rheumatoid arthritis. Ann Rheum Dis 2009, 68:1277-1284.

47. Yeboah J, Burke GL, Crouse JR, Herrington DM: Relationship between brachial flow-mediated dilation and carotid intima-media thickness in an elderly cohort: the Cardiovascular Health Study. Atherosclerosis 2008, 197:840-845

\section{doi:10.1186/ar3382}

Cite this article as: González-Juanatey et al:: Correlation between endothelial function and carotid atherosclerosis in rheumatoid arthritis patients with long-standing disease. Arthritis Research \& Therapy 2011 13: R101.

\section{Submit your next manuscript to BioMed Central and take full advantage of:}

- Convenient online submission

- Thorough peer review

- No space constraints or color figure charges

- Immediate publication on acceptance

- Inclusion in PubMed, CAS, Scopus and Google Scholar

- Research which is freely available for redistribution

Submit your manuscript at www.biomedcentral.com/submit
C Biomed Central 